\title{
Sex Differences in Odor Hedonic Perception: An Overview
}

\author{
Charlotte Bontempi ${ }^{1}$, Laurence Jacquot ${ }^{1}$ and Gérard Brand ${ }^{1,2 *}$ \\ ${ }^{1}$ Laboratoire de Recherches Intégratives en Neurosciences et Psychologie Cognitive - UR481, Université \\ de Franche-Comté, Besançon, France, ${ }^{2}$ CSGA Centre des Sciences du Goût et de l'Alimentation, Dijon, France
}

OPEN ACCESS

Edited by:

Claus-Christian Carbon University of Bamberg, Germany

Reviewed by:

Pengfei Han,

Southwest University, China

Carla Masala

University of Cagliari, Italy

*Correspondence:

Gérard Brand

gerard.brand@univ-fcomte.fr

Specialty section:

This article was submitted to

Perception Science,

a section of the journal

Frontiers in Neuroscience

Received: 25 August 2021 Accepted: 27 September 2021 Published: 18 October 2021

Citation:

Bontempi $C$, Jacquot $L$ and Brand G (2021) Sex Differences in Odor Hedonic Perception: An

Overview.

Front. Neurosci. 15:764520. doi: 10.3389/fnins.2021.764520
Odor hedonic evaluation (pleasant/unpleasant) is considered as the first and one of the most prominent dimension in odor perception. While sex differences in human olfaction have been extensively explored, gender effect in hedonic perception appears to be less considered. However, a number of studies have included comparisons between men and women, using different types of measurements (psychophysical, psychophysiological,...). This overview presents experimental works with non-specific and body odors separately presented as well as experimental studies comparing healthy participants vs patients with psychiatric disorders. Contrary to sensitivity, identification or discrimination, the overall literature tends to prove that no so clear differences occur in odor hedonic judgment between men and women. On the whole, gender effect appears more marked for body than non-specific odors and is almost never reported in psychiatric diseases. These findings are discussed in relation to the processes classically implied in pleasantness rating and emotional processes.

Keywords: olfaction, sex differences, hedonicity, pleasantness rating, emotion

\section{INTRODUCTION}

Chemical senses are crucial in the animal kingdom and are involved in a large variety of adaptative behaviors such as food search, predators avoidance or mates selection. In humans, the processes implied in olfactory perception are well described while the role and the perceptual characteristics of olfaction are currently discussed (Brand, 2020).

The multidimensional aspect of olfaction is related to the three main perceptual characteristics of odors : the intensity (mainly driven by the odorant concentration), the quality (mainly related to the odorant chemical structure) and the hedonic valence corresponding to the pleasant or unpleasant character of the odor. Among them, odor hedonic perception is universally considered as the first and one of the most salient dimension of olfactory perception since a long time (e.g., Moncrieff, 1966; Schiffman, 1974; Land, 1979). Different aspects are usually considered in studies focusing on odor hedonic perception: the odor valence that refers to the pleasant/unpleasant character of odor stimulus, the liking that corresponds to the perceived pleasantness, the wanting that corresponds to the wish to be further exposed to the same odor stimulus and the emotional response that refers to the influence of odor on psychological and physiological states.

Nonetheless, several questions remain unclear such as the relation between the hedonic space of odors and the molecular properties of odorants. Moreover, methodological questions regarding the hedonic assessment of odors make data interpretation difficult and the cortical treatment of odor pleasantness appears highly complex. Overall, studies on odor hedonic perception reveal a large intra- and inter- subject variability and thus an extreme flexibility of odor hedonic perception. In 
sensory hedonic perception, gender is usually considered as a major source of variability and sex differences have been reported in the somatosensory modality (e.g., Jönsson et al., 2017; Novembre et al., 2021), in the gustatory modality (e.g., Cristovam et al., 2000) or in the visual modality (e.g., Sorokowski et al., 2014).

With respect to olfaction, sex differences are well-known and have been largely investigated within different processes such as sensitivity, identification, discrimination or memory in healthy subjects (Brand and Millot, 2002; Doty and Cameron, 2009; Sorokowski et al., 2019) and in patients with neurodegenerative disorders (Melis et al., 2019; Solla et al., 2020). Surprisingly, gender as an influencing factor of hedonic responses to odorants is poorly documented. Because numerous studies considered male and female groups, this paper aims to propose a general overview concerning sex differences in odor hedonic perception. For the sake of clarification, non-specific odors and body odors are separately considered. In the same way, type of task (scale, ranking,...), type of recording (electrophysiological, fMRI,...) and properties of odorant (intensity, pungency,...) are also considered. Finally, characteristics of subjects are taken into account such as mood or psychiatric disorders (depression, schizophrenia,...). The observed differences in odor hedonic perception are discussed in relation to the processes classically implied in pleasantness rating and emotional treatment and could serve usefully in future experimental studies using odors as affective or emotional inducers.

\section{SEX DIFFERENCES IN HEALTHY POPULATIONS: NON-SPECIFIC ODORS}

Data from the literature are reported in two tables, when sex-related differences are demonstrated (Table 1) and when no difference are reported (Table 2). Hedonic judgment is usually evaluated using psychometric (rating scales) and psychophysiological recordings such as electrocardiography (ECG), electroencephalography (EEG), skin conductance response (SCR), or event-related potentials (ERPs), which are sometimes associated with imaging methods. When demonstrated, sex differences in odor hedonic perception seem to be odorant-dependent, albeit not systematic.

\section{Psychometric Studies}

From the beginning of the $20^{\text {th }}$ century, Kenneth (1924) showed that women rated camphor, menthol and ferric valerian as more pleasant than men while the reverse was found for pin oil, cedarwood oil, musk and tonka beans. Later, Wysocki and Gilbert (1989) demonstrated that women rated eugenol and rose as more pleasant than men while the reverse was noted for isoamylacetate and mercaptan. More recently (Seubert et al., 2009), the pleasant vanillin odor was rated as more pleasant by women compared to men whereas no difference was observed for the unpleasant hydrogen sulfide odor as well as for eugenol, a bimodal pleasant/unpleasant odor. In addition, it has been shown that men assessed patchouli oil as more pleasant than women (Trellakis et al., 2011) and women assessed phenyl ethyl alcohol as more pleasant than men (Ferdenzi et al., 2019). Interestingly, in hyposmic populations, no sex difference was observed before treatment whereas after treatment (theophylline) women assessed pyridine and thiphene as more unpleasant than men (Henkin, 2018).

More globally, it seems that women evaluate the pleasantness of perceived odors in a more extreme manner than men for both pleasant and unpleasant polarities (Thuerauf et al., 2009). This observation appears congruent with results obtained from selfrated psychological scales, especially in the case of disgust. For instance, Haidt et al. (1994) used the 32-item Disgust Scale (DS) and showed that women scored higher than men. Factor analyses revealed that DS taps three dimension of disgust: core disgust, animal reminder disgust and contamination-based disgust. It was then demonstrated that women scored higher than men for the three disgust dimensions (Olatunji et al., 2007). Using a specific body odor disgust scale (BODS), Tullio Luizza et al. (2017), revealed a reliable but small effect of gender indicating that women reported a higher level of body odor disgust than men. In another way (Nordin et al., 2004), the CSS scores (Chemical Sensitivity Scale used to quantify affective reactions to odorous/pungent substances in the environment) were found to be higher in women than in men. However, studies carried out in different countries (Ferdenzi et al., 2013; Knaapila et al., 2017) found no sex-related differences in odor hedonic perception whatever the odorants and the country. These discrepancies may be due to several factors, especially the experimental conditions (i.e., type and number of odorants, type of rating scales,...).

Concerning the odorant properties, the perceived intensity, which is related to the stimulus concentration, is an important determinant of hedonic estimation and can reveal gender differences. For instance, women rated several concentrations of pyridine as more unpleasant than men (Broman and Nordin, 2000). These findings were later confirmed with three pyridine concentrations (Olofsson and Nordin, 2004). Additionally, Croy et al. (2017) showed a significant correlation between olfactory threshold and disgust ratings, but only in men. Furthermore, the experimental context can strongly influence many aspects of olfactory perception such as detection threshold (e.g., Rabin and Cain, 1986) discrimination (e.g., Jehl et al., 1995) and hedonicity (e.g., Djordjevic et al., 2008). First, considering repetitive exposure to three pleasant odorant stimuli (coconut, aloe and flowers), Triscoli et al. (2014) demonstrated that perceived pleasantness decreased from the first five presentations in men whereas it remained stable in women. Interestingly, the reverse occurred for "wanting" ratings (defined as "the wish to be further exposed to the same olfactory stimulus") that remained stable in men while it decreased during repetitive stimulations in women. Second, it has been shown that verbal labels associated to odors can influence olfactory perception (Herz and von Clef, 2001). Using odorants from the Sniffin'Stick Identification Test (Hummel et al., 1997), a study compared hedonicity before and after the presentation of an odor label (Seo et al., 2008). Results revealed significant changes for specific odors of cinnamon, rose, cloves and licorice in women and for specific odors of shoe leather, pineapple, lemon in men. However, for coffee odor the effect of odor label was observed in both men and women. With 
TABLE 1 | Summary of studies in healthy populations showing sex differences in odor hedonic perception (non-specific odors and body odors).

\begin{tabular}{|c|c|c|c|c|}
\hline Authors & $\begin{array}{l}\text { Number of subjects } \\
\text { (Male/Female) }\end{array}$ & Number and type of odors & Methods & Results \\
\hline Kenneth, 1924 & Data not available & Non-specific odors & Data not available & $\begin{array}{l}\text { Women judge camphor, menthol, and ferric valerian odors to } \\
\text { being more pleasant than men, whereas the opposite is found } \\
\text { for pine oil, cedarwood oil, musk and tonka beans. }\end{array}$ \\
\hline Doty et al., 1975 & $37 / 41$ adults & Body odors & Magnitude estimation & $\begin{array}{l}\text { Women judge vaginal secretions odors to being more } \\
\text { unpleasant than men. }\end{array}$ \\
\hline Doty et al., 1982 & $5 / 5$ adults & 33 body odors & $\begin{array}{l}\text { Rating scale from "very unpleasant" to "very } \\
\text { pleasant" }\end{array}$ & Women evaluate breath odors as less pleasant than men. \\
\hline $\begin{array}{l}\text { Wysocki and } \\
\text { Gilbert, } 1989\end{array}$ & $43,6 \% / 56,40 \%$ adults & 4 non-specific odors & 5-point scale from unpleasant to pleasant & $\begin{array}{l}\text { Women rate eugenol and rose as more pleasant than men while } \\
\text { the reverse is noted for isoamyl acetate and mercaptan. }\end{array}$ \\
\hline Haidt et al., 1994 & $\begin{array}{l}71 / 111 \text { students } \\
58 / 68 \text { students } \\
109 / 61 \text { students } \\
28 / 18 \text { students }\end{array}$ & Not relevant & 32-item Disgust Scale & Women score higher than men. \\
\hline $\begin{array}{l}\text { Broman and } \\
\text { Nordin, } 2000\end{array}$ & Data not available & 1 non-specific odor & Aversive detection thresholds & $\begin{array}{l}\text { Women present an odor aversion at lower concentrations (i.e., } \\
\text { lower aversive detection threshold) than men, and they evaluate } \\
\text { concentrations above this threshold as more unpleasant. }\end{array}$ \\
\hline Platek et al., 2001 & $18 / 32$ adults & 50 body odors & $\begin{array}{l}\text { Visual analogue scale from } 0 \text { (not at all } \\
\text { pleasant) to } 100 \text { (extremely pleasant) }\end{array}$ & $\begin{array}{l}\text { Women assess their own axillary odors as less pleasant than } \\
\text { men. }\end{array}$ \\
\hline Royet et al., 2003 & $14 / 14$ adults & 126 non-specific odors & functional Magnetic Resonance Imaging & $\begin{array}{l}\text { Between resting and olfactory conditions, men demonstrate } \\
\text { cerebral activations in the bilateral insula and in the left } \\
\text { piriform-amygdala region. } \\
\text { In women activations are located in the same areas as well as in } \\
\text { the left orbitofrontal cortex. }\end{array}$ \\
\hline $\begin{array}{l}\text { Stevenson and } \\
\text { Repacholi, } 2003\end{array}$ & $\begin{array}{l}\text { 23/26 children } \\
19 / 16 \text { teenagers } \\
15 / 15 \text { adults }\end{array}$ & 4 body odors 1 non-specific odor & $\begin{array}{l}\text { 5-point scale with an added visual } \\
\text { component from "I dislike it a lot" to "l like it a } \\
\text { lot." }\end{array}$ & $\begin{array}{l}\text { In children, boys assess female sweat odor as more unpleasant } \\
\text { than girls. } \\
\text { In teenagers, girls rate male sweat odor to being more } \\
\text { unpleasant than boys, and caramel odor as more pleasant than } \\
\text { boys. } \\
\text { In adults, women rate both male and female body odors as } \\
\text { more unpleasant than men. }\end{array}$ \\
\hline $\begin{array}{l}\text { Olofsson and } \\
\text { Nordin, } 2004\end{array}$ & $17 / 19$ adults & 1 non-specific odor & $\begin{array}{l}\text { Category ratio }-10 \text { scale Event-related } \\
\text { potentials }\end{array}$ & $\begin{array}{l}\text { Women give highest unpleasantness ratings, particularly for the } \\
\text { highest odorant (i.e., pyridine) concentration. The amplitude } \\
\text { and the latency of P2/P3 component at Cz position } \\
\text { are, respectively, larger and shorter in women than in men. }\end{array}$ \\
\hline Nordin et al., 2004 & 272/323 adults & Not relevant & Chemical Sensitivity Scale (CSS) & CSS scores are higher in women than in men. \\
\hline Martins et al., 2005 & $\begin{array}{l}\text { 20/20 heterosexual adults } \\
\text { 20/20 homosexual adults }\end{array}$ & 24 body odors & $\begin{array}{l}\text { Forced-choice preference judgments and } \\
\text { strength of preference (10-point scale) }\end{array}$ & $\begin{array}{l}\text { Homosexual men prefer body odors from homosexual men } \\
\text { while both heterosexual men and women as well as } \\
\text { homosexual women prefer body odors from heterosexual men. }\end{array}$ \\
\hline
\end{tabular}


TABLE 1 | (Continued)

\begin{tabular}{|c|c|c|c|c|}
\hline Authors & $\begin{array}{l}\text { Number of subjects } \\
\text { (Male/Female) }\end{array}$ & Number and type of odors & Methods & Results \\
\hline Olatunji et al., 2007 & 249/744 adults (study 2) & Not relevant & 27-items Disgust Scale & $\begin{array}{l}\text { Women score higher than men for the three disgust } \\
\text { dimensions: Core Disgust, Animal Reminder Disgust, and } \\
\text { Contamination-Based Disgust }\end{array}$ \\
\hline Seo et al., 2008 & $53 / 87$ adults & 12 non-specific odors & $\begin{array}{l}\text { 6-points Likert scale ranging from } 1 \text { (very } \\
\text { pleasant) to } 6 \text { (very unpleasant) }\end{array}$ & $\begin{array}{l}\text { Odor hedonic valence is influenced by the presence of a verbal } \\
\text { label. } \\
\text { Hedonic valence is significantly modified for odors of cinnamon, } \\
\text { licorice, rose and clove in women, and for odors of shoe } \\
\text { leather, lemon, and pineapple in men. }\end{array}$ \\
\hline $\begin{array}{l}\text { Thuerauf et al., } \\
2009\end{array}$ & $86 / 86$ adults & 16 non-specific odors & $\begin{array}{l}\text { Two bipolar rating scales: one (relative } \\
\text { hedonic estimates) ranging from }-10 \\
\text { (unpleasant) to }+10 \text { (pleasant) and one } \\
\text { (absolute hedonic estimates) ranging from } 0 \\
\text { to }+10\end{array}$ & $\begin{array}{l}\text { Odor hedonic valence (i.e., both relative and absolute hedonic } \\
\text { estimates) is always higher in women than in men for both } \\
\text { pleasant and unpleasant odors. }\end{array}$ \\
\hline Seubert et al., 2009 & $13 / 12$ adults & 3 non-specific odors & $\begin{array}{l}\text { 7-points Likert scale from }-3 \text { (extremely } \\
\text { unpleasant) to }+3 \text { (extremely pleasant), with } 0 \\
\text { indicating a neutral affective value. }\end{array}$ & $\begin{array}{l}\text { Sex differences are only observed for the pleasant vanillin odor. } \\
\text { Women rate this odor as more pleasant than do men. }\end{array}$ \\
\hline Seo et al., 2009 & $50 / 50$ adults & 6 non-specific odors & $\begin{array}{l}\text { Emotional response test: } 25 \text { paired semantic } \\
\text { differential scales } \\
\text { Odor hedonic rating: } 9 \mathrm{~cm} \text { line scale ranging } \\
\text { from } 0 \text { (extremely dislike) to } 9 \text { (extremely like) }\end{array}$ & $\begin{array}{l}\text { Women prefer odors characterized as more "bright" "faint", } \\
\text { "warm", "common," and, "intellectual". Men prefer odors } \\
\text { characterized as more "refined", "familiar" and "manlike". }\end{array}$ \\
\hline Trellakis et al., 2011 & $17 / 14$ adults & 6 non-specific odors & $\begin{array}{l}100 \mathrm{~mm} \text { visual analog scale) (lowest hedonic } \\
\text { value } 0 \mathrm{~mm} \text {, highest } 100 \mathrm{~mm} \text { ). }\end{array}$ & $\begin{array}{l}\text { For patchouli oil, male subjects showed a significantly higher } \\
\text { odor pleasantness than female. }\end{array}$ \\
\hline Triscoli et al., 2014 & 9/9 adults & 3 non-specific odors & $\begin{array}{l}\text { Visual analog scale from "not at all pleasant" } \\
\text { to "very pleasant" }\end{array}$ & $\begin{array}{l}\text { From the 5th presentation, the perceived pleasantness } \\
\text { decreases in men while it remains constant in women. }\end{array}$ \\
\hline $\begin{array}{l}\text { Hoffmann-Hensel } \\
\text { and Freiherr, } 2016\end{array}$ & 13/12 right-handers' adults & 4 non-specific odors & $\begin{array}{l}\text { Physiological responses (Skin conductance } \\
\text { responses and breathing data) Behavioral } \\
\text { responses (odor perception reaction times) }\end{array}$ & $\begin{array}{l}\text { Only men show differences related to the pleasantness of odors } \\
\text { for skin conductance responses. }\end{array}$ \\
\hline $\begin{array}{l}\text { Tullio Luizza et al., } \\
2017\end{array}$ & $285 / 233$ & Not relevant & Body odor Disgust Scale & Women report a higher level of body odor disgust than men. \\
\hline Henkin, 2018 & $134 / 178$ adults & 4 non-specific odors & $\begin{array}{l}\text { Scale from } 0 \text { to } 100 \text { reflecting pleasantness } \\
\text { and scale from } 0 \text { to }-100 \text { reflecting } \\
\text { unpleasantness }\end{array}$ & $\begin{array}{l}\text { No sex differences before treatment. } \\
\text { After treatment ( } 400 \text { and } 600 \mathrm{mg} \text { of oral theophylline) women } \\
\text { assess pyridine and thiophene as more unpleasant than men. }\end{array}$ \\
\hline $\begin{array}{l}\text { Ferdenzi et al., } \\
2019\end{array}$ & $\begin{array}{l}\text { 20/20 French adults } \\
\text { 175/105 Malagasy adults }\end{array}$ & 1 non-specific odor & $\begin{array}{l}\text { Scale from } 1 \text { (not at all pleasant) from } 7 \text { (very } \\
\text { pleasant) }\end{array}$ & $\begin{array}{l}\text { Sex differences are only found in French participants. } \\
\text { Women rate phenylethyl alcohol as more pleasant than men. }\end{array}$ \\
\hline
\end{tabular}


TABLE 2 | Summary of studies in healthy populations showing no sex differences in odor hedonic perception (non-specific odors and body odors).

\begin{tabular}{|c|c|c|c|c|}
\hline Authors & $\begin{array}{l}\text { Number of subjects } \\
\text { (Male/Female) }\end{array}$ & Type of odors & Methods & Results \\
\hline Doty et al., 1978 & $10 / 10$ adults & 10 body odors & Magnitude estimation & $\begin{array}{l}\text { No sex differences. } \\
\text { However, in both men and women, female } \\
\text { axillary odors are judged weaker and less } \\
\text { unpleasant than male axillary odors. }\end{array}$ \\
\hline $\begin{array}{l}\text { Brand and Jacquot, } \\
2001\end{array}$ & $15 / 15$ right-handed adults & 4 non-specific odors & Skin conductance responses & No sex differences. \\
\hline Bensafi et al., 2002b & $10 / 22$ adults & 2 non-specific odors & $\begin{array}{l}\text { Scale from } 0 \text { (not at all pleasant) to } 5 \\
\text { (extremely pleasant) } \\
\text { Response times }\end{array}$ & No sex differences. \\
\hline Bensafi et al., 2002a & $8 / 10$ adults & 6 non-specific odors & $\begin{array}{l}\text { Likert scale from } 1 \text { (not at all pleasant) to } 9 \\
\text { (extremely pleasant) } \\
\text { Heart rate and skin conductance }\end{array}$ & No sex differences. \\
\hline $\begin{array}{l}\text { Lundström and } \\
\text { Hummel, } 2006\end{array}$ & $17 / 17$ adults & 1 non-specific odor & $\begin{array}{l}\text { Event-related potentials } \\
\text { Visual scale ranging from } 0 \text { (unpleasant) to } \\
100 \text { (pleasant). }\end{array}$ & $\begin{array}{l}\text { No sex differences in hedonic ratings However, } \\
\text { women express larger amplitudes and longer } \\
\text { latencies in the left hemisphere, } \\
\text { whereas in men this phenomenon occurs in the } \\
\text { right hemisphere. }\end{array}$ \\
\hline Boesveldt et al., 2010 & 20/20 adults & 4 non-specific odors & $\begin{array}{l}\text { Visual analogue scale from "extremely } \\
\text { unpleasant" to "extremely pleasant" } \\
\text { Reaction times }\end{array}$ & No sex differences. \\
\hline Knaapila et al., 2012 & $153 / 244$ adults & 1 body odor & $\begin{array}{l}\text { 9-point Likert scale ranging from } 0 \\
\text { (extremely unpleasant) to } 9 \text { (extremely } \\
\text { pleasant) through } 5 \text { (neither unpleasant, nor } \\
\text { pleasant) }\end{array}$ & $\begin{array}{l}\text { No sex differences. } \\
\text { However, in women hedonic rating of } \\
\text { androstenone is related to sexual intercourse } \\
\text { experiences }\end{array}$ \\
\hline Ferdenzi et al., 2013 & $\begin{array}{l}\text { 59/151 adults from Geneva } \\
\text { 144/207 adults from Liverpool } \\
\text { 87/124 adults from Singapore }\end{array}$ & $\begin{array}{l}56 \text { (in Geneva and Liverpool) and } \\
59 \text { (in Singapore) non-specific } \\
\text { odors }\end{array}$ & $\begin{array}{l}\text { Visual analog scale labeled from } 0 \text { (not at all } \\
\text { pleasant) to } 200 \text { (extremely pleasant) }\end{array}$ & No sex differences. \\
\hline Lübke and Pause, 2014 & $26 / 25$ adults & 1 body odor & $\begin{array}{l}\text { Scale from } 0 \text { (not at all pleasant) to } 10 \\
\text { (extremely pleasant) }\end{array}$ & $\begin{array}{l}\text { No sex differences. } \\
\text { However, in men with higher testosterone level, } \\
\text { androstenone is perceived as more unpleasant } \\
\text { than in men with lower testosterone level. } \\
\text { Similarly, in women with higher estradiol level, } \\
\text { androstenone is perceived as more unpleasant } \\
\text { than in women with lower estradiol level }\end{array}$ \\
\hline Mutic et al., 2016 & $15 / 16$ adults & 27 body odors & $\begin{array}{l}\text { Visual analog scale from } 0 \text { (not pleasant) to } \\
100 \text { (extremely pleasant) }\end{array}$ & $\begin{array}{l}\text { No sex differences. } \\
\text { However, women body odor is globally rated as } \\
\text { less pleasant than men body odor. }\end{array}$ \\
\hline Knaapila et al., 2017 & $33 / 93$ adults & 12 non-specific odors & 9 -point scale from -4 to +4 & No sex differences. \\
\hline Ferdenzi et al., 2019 & $\begin{array}{l}\text { 20/20 French adults } \\
\text { 175/105 Malagasy adults }\end{array}$ & 3 body odors & $\begin{array}{l}\text { Scale from } 1 \text { (not at all pleasant) to } 7 \text { (very } \\
\text { pleasant) }\end{array}$ & No sex differences. \\
\hline
\end{tabular}


an other paradigm, Seo et al. (2009) asked participants to rate the emotional responses of dairy odors using 25 adjective pairs (e.g., common/rare, natural/artificial, usual/unusual, attractive, denial,...) as well as the hedonicity using a line scale. Results showed that both men and women preferred dairy odors that were characterized as more "comfortable," "attractive " and "fragrant." However, women preferred odors characterized as more "bright," "faint," "warm," "common" and "intellectual," while men preferred odors characterized as more "refined," "familiar" and "manlike."

Finally, several comparative exposure conditions have not been yet explored. For instance, the hypothesis that gender differences in odor hedonic perception could be related to the nostril stimulated (Brand et al., 2001; Disjkersrhuis et al., 2002) would be worth investigating. Additionally, further studies are needed to compare ortho versus retronasal stimulations or to examine the impact of the odorant qualities. For instance, the impact of trigeminal component of odorants (Brand, 2006) has never been explored, except in the study of Wallrabenstein et al. (2015) suggesting that the activation of VN1R1 by hedione might play a role in sex-specific modulation of hormonal secretion in humans. More specifically, because of the importance of pleasantness in food consumption, research should explore the role of food composition in sensory attributes evaluation. As a precursor, the work of Rosa et al. (2020) showed that women exhibited a greater ability than men to detect pleasantness of an odor rich in free fatty acid such as the mullet roes.

\section{Psychophysiological and Imagery Studies}

A number of studies have used psychophysiological measures (SCR, ECG, EEG, or ERPs) in response to pleasant and unpleasant odors (e.g., Alaoui-Ismaili et al., 1997a; Glass et al., 2014). Independently from gender, results showed a more marked effect with unpleasant odors compared to pleasant odors. Surprisingly, gender differences in odor hedonic perception using psychophysiological measures are poorly documented, contrary to psychometric measurements. Some studies included only women (e.g., He et al., 2014, 2016; Pichon et al., 2015) or did not consider sex differences (e.g., Alaoui-Ismaili et al., 1997b; Bensafi, 2002; Djordjevic et al., 2008; Ferdenzi et al., 2017). Some other works compared men and women in skin conductance, heart rate responses or reaction time using pleasant and unpleasant odors (Brand and Jacquot, 2001; Bensafi et al., 2002a,b; Boesveldt et al., 2010). Data revealed no gender-related differences according to the hedonic valence of odorants. By contrast, in an other study (Hoffmann-Hensel and Freiherr, 2016), only men showed differences related to the pleasantess of odors (orange, cherry, vomit and spoiled fish) in skin conductance responses. Using ERPs with the bimodal odor of peppermint oil, Lundström and Hummel (2006) demonstrated that, although there were no differences in hedonic ratings between men and women, a sexrelated difference occurred in hemispheric responses, i.e., women expressed larger amplitudes and longer latencies in the left hemisphere while the same phenomenon was found in the right hemisphere in men. Another study (Olofsson and Nordin, 2004) conducted with three concentrations of pyridine indicated that the amplitude and the latency of $\mathrm{P} 2 / \mathrm{P} 3$ component at $\mathrm{Cz}$ position were, respectively, larger and shorter in women than in men.

For several years, research concerning brain activity in olfactory perception, especially in hedonic perception, seeks to determine cerebral areas activation and to understand the underlying mechanisms (Zou et al., 2016) that are always currently discussed (Ruser et al., 2021). However, few studies have considered gender, probably because the number of participants recruited was small. Among them, the study of Royet et al. (2003) reported differential activation in men and in women, particularly in the left orbitofrontal cortex.

\section{SEX DIFFERENCES IN HEALTHY POPULATIONS: BODY ODORS}

There is evidence that body odors are involved in human communication and contribute to social interactions in daily life. Indeed, body odors carry important information relating to emotional state (de Groot et al., 2015), mate selection and attractiveness (Singh and Bronstad, 2001) as well as hormonal state (Preti et al., 1986, 2003). Body odors derive from volatile compounds present in urine, vaginal secretions or breath and produced by degradation of bacteria on human skin (e.g., axillary zone, feet,...). These odors are mainly composed of aldehydes, ketones and carboxylic acid (Natsch and Emter, 2020). In the current society, body odors are usually perceived as unpleasant although interindividual differences have been reported, particularly between men and women.

In a pioneer study (Doty et al., 1975), vaginal secretions were collected from four women during 15 consecutives menstrual cycle and the odor pleasantness was rated by both men and women. Results clearly showed that women assessed the odors as more unpleasant than men. In the same way (Doty et al., 1978), hedonic valence of male and female axillary odors were rated by men and women and no difference was observed. In contrast (Doty et al., 1982), when both men and women rated male and female breath odors, the breath odor of males were rated as more intense and less pleasant than the breath odor of females. In addition, women gave significant lower pleasantness ratings to the breath odors than men. Interestingly, both men and women assigned the breath odor to the correct gender class and an inverse relation between breath odor intensity and pleasantness was observed. Concerning body odors, usually collected using T-shirt, cotton or gauze pieces placed under armpits, it appears that women assessed their own body odor as less pleasant than did men toward theirs (Platek et al., 2001). A comparative study (Stevenson and Repacholi, 2003), examined the hedonic estimation of body odor from adults by children, teenagers and adults. In children, boys rated women body odors as more unpleasant than girls while in teenagers, girls rated men body odors as more unpleasant than boys. In adults, women rated both male and female body odors as more unpleasant than men.

However, several factors could influence the hedonic estimation of body odors. For instance, the hypothesis that sexual orientation of donor could induce changes in pleasantness rating 
has been tested (Martins et al., 2005). Results indicated that homosexual men preferred body odors from homosexual men while both heterosexual men and women as well as homosexual women preferred body odors from heterosexual men. In another way (Mutic et al., 2016), a comparative analysis assessed the pleasantness of body odors collected during an intensive physical exercise and showed that women body odor was globally rated as less pleasant than those of men without sex-related differences.

Among body odors, androstenone is probably the most studied in experimental research. Androstenone is a steroid hormone commonly found in sweat and urine of male mammalians. In humans, androstenone is present in axillary regions in greater quantity in men than in women (Gower et al., 1985). Because of a large genetic polymorphism of genes encoding the olfactory receptors (ORs) among human's population, many people and mostly men cannot detect androstenone (Wysocki and Beauchamp, 1984; Bremmer et al., 2003). Like other smells, the pleasantness of androstenone is context-dependent: perceived as unpleasant when associated with urine and sweat or perceived as pleasant when associated with floral cues (Hasin-Brumstein et al., 2009). Surprisingly, although androstenone is widely studied, few publications have been dedicated to gender differences. Elsewhere, several experiments considered additional specific parameters that are possibly related to androstenone pleasantness. For instance (Lübke and Pause, 2014), in men with higher testosterone level, androstenone was perceived as more unpleasant than in men with lower testosterone level. Similarly, in women with higher estradiol level, androstenone was perceived as more unpleasant than in women with lower estradiol level. In another way, it has been suggested (Knaapila et al., 2012) that specifically in women, hedonic rating of androstenone is related to sexual intercourse experiences. Indeed, androstenone is rated as more pleasant by women who had a sexual intercourse experience with at least one partner, compared to those who reported never had sexual intercourse. Finally, the unique study comparing the hedonic perception of androstenone in relation to gender (Ferdenzi et al., 2019) found no sex differences for any of the perceptual variables, including pleasantness.

\section{SEX DIFFERENCES IN PSYCHIATRIC DISORDERS}

Olfactory deficits have been reported in psychiatric diseases, particularly in schizophrenia, depressive and bipolar disorders (e.g., Atanasova et al., 2008; Turetsky et al., 2009; Lahera et al., 2016; Brand and Schaal, 2017; Kamath et al., 2017; Kiparizoska and Ikuta, 2017). Patients usually presented lower olfactory sensitivity, discrimination and identification scores than healthy people (e.g., Postolache et al., 2002; Chen et al., 2018). Moreover, it has long been shown that in these diseases, olfactory impairment is stage-dependent and treatment-dependent in these diseases as it has been shown for a long time (GrossIsseroff et al., 1994; Sirota et al., 1999). Olfactory dysfunction could also be disease-specific as suggested in a comparative study between bipolar, depressive and schizophrenic patients
(Li et al., 2021). However, some brain areas such as amygdala, hippocampus, insula, anterior cingulate cortex and orbitofrontal cortex, involved in the above-mentioned psychiatric disorders especially mood disorders - are linked to the olfactory system in relation to odor hedonic perception (e.g., Soudry et al., 2011). This relationship warrants further experimental studies on odor pleasantness ratings.

In schizophrenia, both men and women overevaluated the pleasantness of isoamyl acetate at high concentrations and underrated the lower concentrations compared to healthy subjects (Kamath et al., 2013). By contrast, another study (Walsh-Messinger et al., 2018) showed that schizophrenic men rated pleasant odors (orange, apple, mint,...) less pleasant than healthy men whereas no difference was observed between healthy and schizophrenic women. When studies related to this topic focused on gender differences in patients with schizophrenia, some of them showed that schizophrenic men rated pleasant odorants as more pleasant than schizophrenic women and healthy participants whatever the concentration level (Moberg et al., 2003; Robabeh et al., 2015). Other studies found no gender differences in odor hedonic judgment (Hudry et al., 2002; Lui et al., 2020).

In depression, the disease effect on odor hedonic ratings is not clearly demonstrated (e.g., Lombion-Pouthier et al., 2006; Swiecicki et al., 2009; Atanasova et al., 2010). When gender effect was considered in depression (Clepce et al., 2010), no difference between men and women was found in odor hedonic judgment. Similar data were obtained in bipolar disorder patients (Cummings et al., 2011) although the authors noted that women tended (i.e., in a non-significant way) to rate pleasant and unpleasant odors as more pleasant than men.

\section{CONCLUSION}

Contrary to sensitivity, identification or discrimination, this overview tends to prove that not such a clear differences occur in odor hedonic estimation between men and women. Gender effect appears more marked for body than for non-specific odors and is almost never reported in psychiatric diseases. It must be noted that no published study has yet focused on gender effect in odor hedonic estimation in neurodegenerative diseases (Alzheimer, Parkinson,...) while olfactory capabilities have been largely assessed (e.g., Doty, 2012; Woodward et al., 2017). When differences are reported, albeit not systematic, it seems that women overrated pleasant odors and underrated unpleasant odors compared to men. In accordance with the view that the hedonic processing of odor stimuli is an emotional rather than an analytical task and because sex differences occur in emotion (Wester et al., 2002), gender should logically affect clearly both the polarity and the extremity of the odor hedonic estimates. Thus, these findings regarding odor hedonic perception are rather surprising insofar as women are considered more responsive to emotional stimuli than men (Lithari et al., 2010) including auditory stimuli such as music and sounds, emotional words or emotional tones of voice (e.g., Schirmer et al., 2002, 2005; Bachorowski and Owren, 2003) visual stimuli such as 
pictures and films (see Cahill, 2006 for a review) or danger-related stimuli (Williams and Gordon, 2007).

Additionally, except for pyridine and androstenone, there is not enough consistent data to draw conclusions on particular odorants. Moreover, most of studies focus on several parameters and rarely only on hedonic estimation. Thus, the odorants, tasks and participant characteristics are generally heterogeneous from one study to another (Clepce et al., 2014) which induces discrepancies and makes an overall conclusion difficult.

The main hypothesis related to this tenuous difference between men and women probably concerns the great intraand inter-variability in hedonic responses to odors. Indeed, numerous factors can influence odor perception (Greenberg et al., 2013) and certainly can influence the hedonic estimates and leveled the scores into groups of participants. Interindividual differences can occur in relation to sensitivity, familiarity, experience and memory toward the odorant stimulus (e.g., Delplanque et al., 2008), as well as in relation to age, culture, eating habits, medication and personality traits. Intraindividual differences can occur in relation to physiological states (e.g., arousal, weariness, stress, hunger,...), hormonal states

\section{REFERENCES}

Alaoui-Ismaili, O., Robin, O., Rada, H., Dittmar, A., and Vernet-Maury, E. (1997a). Basic emotions evoked by odorants: comparison between autonomic responses and self-evaluation. Physiol. Behav. 62, 713-720. doi: 10.1016/S0031-9384(97) 90016-0

Alaoui-Ismaiili, O., Vernet-Maury, E., Dittmar, A., Delhomme, G., and Chanel, J. (1997b). Odor hedonics: connection with emotional responses estimated by autonomic parameters. Chem. Senses. 22, 237-248. doi: 10.1093/chemse/22.3. 237

Atanasova, B., El-Hage, W., Chabanet, C., Gaillard, P., Belzung, C., and Camus, V. (2010). Olfactory anhedonia and negative olfactory alliesthesia in depressed patients. Psychiatry Res. 176, 190-196. doi: 10.1016/j.psychres.2008.11.016

Atanasova, B., Graux, J., El Hage, W., Hommet, C., Camus, V., and Belzung, C. (2008). Olfaction: a potential cognitive marker of psychiatric disorders. Neurosci. Biobehav. Rev. 32, 1315-1325. doi: 10.1016/j.neubiorev.2008.05.003

Bachorowski, J., and Owren, M. J. (2003). Sounds of emotion production and perception of affect-related vocal acoustics. Ann. N.Y.Acad. Sci. 1000, 244-265. doi: 10.1196/annals.1280.012

Becker, S., Bräscher, A. K., Bannister, S., Bensafi, M., Calma-Birling, D., Chan, R. C. K., et al. (2019). The role of hedonics in the human affectome. Neurosci. Biobehav. Rev. 102, 221-241. doi: 10.1016/j.neubiorev.2019.05.003

Bensafi, M. (2002). Autonomic nervous system responses to odours. the role of pleasantness and arousal. Chem. Senses. 27, 703-709. doi: 10.1093/chemse/27. 8.703

Bensafi, M., Rouby, C., Farget, V., Bertrand, B., Vigouroux, M., and Holley, A. (2002a). Influence of affective and cognitive judgments on autonomic parameters during inhalation of pleasant and unpleasnant odors in humans. Neurosci. Lett. 319, 162-166. doi: 10.1016/S0304-3940(01)02572-1

Bensafi, M., Rouby, C., Farget, V., Vigouroux, M., and Holley, A. (2002b). Asymmetry of pleasant vs unpleasant odor processing during affective judgment in humans. Neurosci. Lett. 328, 309-313. doi: 10.1016/S03043940(02)00548-7

Boesveldt, S., Frasnelli, J., Gordon, A. R., and Lundström, J. N. (2010). The fish is bad: negative food odors elicit faster and more accurate reactions than other odors. Biol. Psychol. 84, 313-317. doi: 10.1016/j.biopsycho.2010.03.006

Brand, G. (2006). Olfactory/trigeminal interactions in nasal chemoreception. Neurosci. Biobehav. Rev. 30, 908-917. doi: 10.1016/j. neubiorev.2006.01.002 (e.g., Trellakis et al., 2011) and psychological states (attention, motivation, mood,...). Besides, intra- and inter-individual differences in odor preferences are not specific to humans and have been reported in animals (e.g., Jagetia et al., 2018) in rigorously homogeneous cohorts. This suggests that odor hedonic perception is a highly complex response that prevents direct and relevant comparisons between men and women in the general population. Besides, current research demonstrates that individual pleasantness of odors is not detectable in fMRI (Ruser et al., 2021), probably because this process is coded in joint networks (Mantel et al., 2019). Thus, future research in this field - especially food studies, toxicological or specific exposure studies, quality of life studies, must cross several factors in a multidimensional approaches among which gender could be included in order to contribute to the knowledge of the human affective neurosciences (Becker et al., 2019).

\section{AUTHOR CONTRIBUTIONS}

All authors listed have made a substantial, direct and intellectual contribution to the work and approved it for publication.

Brand, G. (2020). Discovering Odors. London: Whiley, ISTE. doi: 10.1002/ 9781119687467

Brand, G., and Jacquot, L. (2001). Quality of odor and olfactory lateralization processes in humans. Neurosci. Lett. 316, 91-94. doi: 10.1016/S0304-3940(01) 02375-8

Brand, G., and Millot, J. L. (2002). Sex differences in human olfaction: between evidence and enigma. Quart. J. Exp. Psychol. 54, 259-270. doi: 10.1080/ 02724990143000045

Brand, G., Millot, J. L., and Henquell, D. (2001). Complexity of olfactory lateralization processes revealed by functional imaging: a review. Neurosci. Biobehav. Rev. 25, 159-166. doi: 10.1016/S0149-7634(01)00005-7

Brand, G., and Schaal, B. (2017). Olfaction in depressive disorders : issues and perspectives. Encephale 43, 176-182. doi: 10.1016/j.encep.2016. 04.008

Bremmer, E. A., Mainland, J. D., Khan, R. M., and Sobel, N. (2003). The prevalence of androstenone anosmia. Chem. Senses. 28, 423-432. doi: 10.1093/chemse/28. 5.423

Broman, D. A., and Nordin, S. (2000). Olfactory gender differences in sensation and perception. Int. J. Psychol. 35:329.

Cahill, L. (2006). Why sex matters for neuroscience. Nat. Rev. Neurosci. 7, 477-484. doi: 10.1038/nrn1909

Chen, X., Xu, J., Li, B., Guo, W., Zhang, J., and Hu, J. (2018). Olfactory impairment in first-episode schizophrenia: a case-control study and sex dimorphism in the relationship between olfactory impairment and psychotic symptoms. BMC Psychiatry 18:1786-1788. doi: 10.1186/s12888-018-1786-8

Clepce, M., Gossler, A., Reich, K., Kornhuber, J., and Thuerauf, N. (2010). The relation between depression, anhedonia and olfactory estimates: a pilot study in major depression. Neurosci. Lett. 471, 139-143. doi: 10.1016/j.neulet.2010. 01.027

Clepce, M., Neumann, K., Martus, P., Nitsch, M., Wielopolski, J., Koch, A., et al. (2014). The psychophysical assessment of odor valence: does an anchor stimulus influence the hedonic evaluation of odors? Chem. Senses. 39, 17-25. doi: 10.1093/chemse/bjt050

Cristovam, E., Russell, C., Paterson, A., and Reid, E. (2000). Gender preference in hedonic ratings for espresso and espresso-milk coffees. Food Q. Preference 11, 437-444. doi: 10.1016/S0950-3293(00)00015-X

Croy, I., Bendas, J., Wittrodt, N., Lenk, M., Jorschky, P., and Weidner, K. (2017). Gender-specific relation between olfactory sensitivity and disgust perception. Chem. Senses. 42, 487.492. doi: 10.1093/chemse/bjw163 
Cummings, A. G., Mathhiews, N. L., and Park, S. (2011). Olfactory identification and preference in bipolar disorder and schizophrenia. Eur. Arch. Psychiatry Clin. Neurosci. 261, 251-259. doi: 10.1007/s00406-010-0145-7

de Groot, J. H. B., Smeets, M. A. M., Rowson, M. J., Bulsing, P. J., Blonk, C. G., and Wilkinson, J. E. (2015). A sniff of happiness. Psychol. Sci. 26, 684-700. doi: $10.1177 / 0956797614566318$

Delplanque, S., Grandjean, D., Chrea, C., Aymard, L., Cayeux, I., Le Calvé, B., et al. (2008). Emotional processing of odors: evidence for a nonlinear relation between pleasantness and familiarity. Chem. Senses. 33, 469-479. doi: 10.1093/ chemse/bjn014

Disjkersrhuis, G. B., Møller, P., Bredie, W. L. P., Rasmussen, G., and Martens, M. (2002). Gender and handedness effects on hedonicity of laterally presented odours. Brain Cogn. 50, 272-281. doi: 10.1016/S0278-2626(02)00511-0

Djordjevic, J., Lundstrom, J. N., Clément, F., Boyle, J. A., Poulliot, S., and JonesGotman, M. (2008). A rose by any other name: would it smell as sweet? J. Neurophysiol. 99, 386-393. doi: 10.1152/jn.00896.2007

Doty, R. L. (2012). Olfaction in Parkinson'disease and related disorders. Neurobiol. Dis. 46, 527-552. doi: 10.1016/j.nbd.2011.10.026

Doty, R. L., and Cameron, E. L. (2009). Sex differences and reproductive hormone influences on human odor perception. Physiol. Behav. 97, 213-228. doi: 10 1016/j.physbeh.2009.02.032

Doty, R. L., Ford, M., Preti, C., and Huggins, G. R. (1975). Changes in the intensity and pleasantness of human vaginal odors during the menstrual cycle. Science 190, 1316-1318. doi: 10.1126/science. 1239080

Doty, R. L., Green, P. A., Ram, C., and Yankell, S. L. (1982). Communication of gender from human breath odors: Relationship to perceived intensity and pleasantness. Hormones Behav. 16, 13-22. doi: 10.1016/0018-506X(82)90002-2

Doty, R. L., Orndorff, M. M., Leyden, J., and Kligman, A. (1978). Communication of gender from human axillary odors: relationship to perceived inetnsity and hedonicity. Behav. Biol. 23, 373-380. doi: 10.1016/S0091-6773(78)91393-7

Ferdenzi, C., Joussain, P., Digard, B., Luneau, L., Djordjevic, J., and Bensafi, M. (2017). Individual differences in verbal and non-verbal affective responses to smells: influence of odor label acroos cultures. Chem. Senses. 42, 37-46. doi: 10.1093/chemse/bjw098

Ferdenzi, C., Razafindrazaka, H., Baldovini, N., Poupon, D., Pierron, D., and Bensafi, M. (2019). Influence of gender and culture on the perception of acidic compounds of human body odor. Physiol. Behav. 210:112561. doi: 10.1016/j. physbeh.2019.112561

Ferdenzi, C., Roberts, S. C., Schirmer, A., Delplanque, S., Cekic, S., and Porcherot, C. (2013). Variability of affective responses to odors: culture, gender and olfactory knowledge. Chem. Senses. 38, 175-186. doi: 10.1093/chemse/bjs083

Glass, S. T., Lingg, E., and Heuberger, E. (2014). Do ambient urban odors evoke basic emotions? Front. Psychol. 5:1-11. doi: 10.3389/fpsyg.2014. 00340

Gower, D. B., Bird, S., Sharma, P., and House, F. R. (1985). Axillary 5 $\alpha$-andro-16ene-3-one in men and women: relationships with olfactory acuity to odorous 16-androstenes. Experientia 41, 1134-1136. doi: 10.1007/BF01951694

Greenberg, M. I., Curtis, J. A., and Vearrier, D. (2013). The perception of odor is not surrogate marker for chemical exposure: a rebiew of factors influencing human odor perception. Chem. Toxicol. 51, 70-76. doi: 10.3109/15563650.2013.767908

Gross-Isseroff, R., Luca-Haimovici, K., Sasson, Y., Kindler, S., Kotler, M., and Zohar, J. (1994). Olfactory sensitivity in major depressive disorder and obsessive compulsive disorder. Biol. Psychiatry 35, 798-802. doi: 10.1016/0006-3223(94) 91142-8

Haidt, J., McCauley, C., and Rozin, P. (1994). Individual differences in sensitivity to disgust: a scale sampling seven domains of disgust elicitors. Personal. Indiv. Diff. 16, 701-713. doi: 10.1016/0191-8869(94)90212-7

Hasin-Brumstein, Y., Lancet, D., and Olender, T. (2009). Human olfaction: from genomic variation to phenotypic diversity. Trends Genet. 25, 178-184. doi: 10.1016/j.tig.2009.02.002

He, W., Boesveldt, S., de Graff, C., and de Wijk, R. A. (2014). Dynamics of autonomic nervous system responses and facial expressions to odors. Front. Psychol. 5:110. doi: 10.3389/fpsyg.2014.00110

He, W., de Wijk, R. A., de Graff, C., and Boesveldt, S. (2016). Implicit and explicit measurments of affective responses to food odors. Chem. Senses. 41, 661-668. doi: 10.1093/chemse/bjw068

Henkin, R. I. (2018). Gender differences in hyposmic men and women. J. Otolaryngol. ENT Res. 10, 240-246. doi: 10.15406/joentr.2018.10.00354
Herz, R. S., and von Clef, J. (2001). The influence of verbal labelling on the perception of odors: evidence for olfactory illusions? Perception 30, 381-391. doi: $10.1068 / \mathrm{p} 3179$

Hoffmann-Hensel, S. M., and Freiherr, J. (2016). Intramodal olfactory priming of positive and negative odors in humans using respiration-triggered olfactory stimulation (RETROS). Chem. Senses. 41, 567-578. doi: 10.1093/chemse/ bjw060

Hudry, J., Saoud, M., D’Amaton, T., Daléry, J., and Royet, J. P. (2002). Ratings of different olfactory judgments in schizphrenia. Chem. Senses. 27, 407-416. doi: 10.1093/chemse/27.5.407

Hummel, T., Sekinger, B., Wolf, S. R., Pauli, E., and Kobal, G. (1997). "Sniffin Sticks": olfactory performance assessed by the combined testing of odor identification, odor discrimination and olfactory threshold. Chem. Senses. 22, 39-52. doi: 10.1093/chemse/22.1.39

Jagetia, S., Milton, A., Stetzik, L. A., Liu, S., Pai, K., Arakawa, K., et al. (2018). Inter-and intra-mouse variability in odor preferences revealed in an olfactory multiple choice test. Behav. Neurosci. 132, 88-98. doi: 10.1037/bne00 00233

Jehl, C., Royet, J. P., and Holley, A. (1995). Odor discrimination and recognition memory as a function of familiarization. Perception Psychophys. 57, 1002-1011. doi: 10.3758/BF03205459

Jönsson, E. H., Bendas, J., Weidner, K., Wessberg, J., Olausson, H., Wasling, H. B., et al. (2017). The relation between human hair follicle density and touch perception. Sci. Rep. 7:2499. doi: 10.1038/s41598-017-02308-9

Kamath, V., Moberg, P. J., Kholer, C. G., Gur, R. E., and Turetsky, B. I. (2013). Odor hedonic capacity and anhedonia in schizophrenia and unaffected firstdegree relatives of schizophrenia patients. Schizophrenia Bull. 39, 59-67. doi: 10.1093/schbul/sbr050

Kamath, V., Paksarian, D., Cui, L., Moberg, P. J., Turetski, B. I., and Merikangas, K. R. (2017). Olfactory processing in bipolar disorder, major depression, and anxiety. Bipolar Dis. 20,547-555. doi: 10.1111/bdi.12625

Kenneth, J. (1924). Some experiments on mental reactions to odours. Perfumery Essential Oil Record. 15, 85-87.

Kiparizoska, S., and Ikuta, T. (2017). Disrupted olfactory integration in schizophrenia: functional connectivity study. Int. J. Psychopharmacol. 20, 740 746. doi: 10.1093/ijnp/pyx045

Knaapila, A., Laaksonen, O., Virtanen, M., Yang, B., Lagström, H., and Sandell, M. (2017). Pleasantess, familiarity and identification of spice odors are interrelated and enhanced by consumption of herbs and food neophilia. Appetite 109, 190-200. doi: 10.1016/j.appet.2016.11.025

Knaapila, A., Tuorila, H., Vuoksimaa, E., Keskitalo-Vuokko, K., Rose, R. J., and Kaprio, J. (2012). Pleasantness of the odor of androstenone as a function of sexual intercourse experience in women and men. Arch. Sexual Behav. 41, 1403-1408. doi: 10.1007/s10508-011-9804-7

Lahera, G., Ruiz-Murugarren, S., Fernandez-Liria, A., Saiz-Ruiz, J., Buck, B. E., and Penn, D. (2016). Relationship between olfactory function and social cognition in euthymic bipolar patients. CNS Spectrums 21, 53-59. doi: 10.1017/ S1092852913000382

Land, D. G. (1979). "Hedonic response and perceived characteristics of odours in man," in Prefernce Brhavior and Chemoreception, ed. J. H. A. Kroeze (London: IRL Press), 193-204.

Li, S. B., Li, Z. T., Lyu, Z. H., Zhang, X. Y., and Zou, L. Q. (2021). Odour identification impairment is a trait but not a disease-specific marker for bipolar disroders: comparisons of bipolar disroder with different episodes, major depressive disorder and schizophrenia. Aust. N. Z. J. Psychiatry. [Epub ahead of print]., doi: 10.1177/0004867421998774

Lithari, C., Frantzidis, C. A., Papadelis, C., Vivas, A. B., Klados, M. A., KourtidouPapdeli, C., et al. (2010). Are females more responsive to emotional stimuli ? A neurophysiological study across arousal and valence dimensions. Brain Topogr. 23, 27-40. doi: 10.1007/s10548-009-0130-5

Lombion-Pouthier, S., Vandel, P., Nezelof, S., Haffen, E., and Millot, J. L. (2006). Odor perception in patients with mood disorders. J. Affect. Disord. 90, 187-191. doi: 10.1016/j.jad.2005.11.012

Lübke, K. T., and Pause, B. M. (2014). Sex-hormone dependent perception of androstenone suggests its involvement in communicating competition and aggression. Physiol. Behav. 123, 136-141. doi: 10.1016/j.physbeh.2013.10.016

Lui, S. S. Y., Chiu, M. W. Y., Chui, W. W. H., Wong, J. O. Y., Man, C. M. Y., and Cheung, E. F. C. (2020). Impaired olfactory identification and hedonic 
judgment in schizophrenia patients with prominent negative symptoms. Cogn. Neuropsychiatry. 25, 126-138. doi: 10.1080/13546805.2019.1704709

Lundström, J. N., and Hummel, T. (2006). Sex-specific hemispheric differences in cortical activation to a bimodal odor. Behav. Brain Res. 166, 197-203. doi: 10.1016/j.bbr.2005.07.015

Mantel, M., Ferdenzi, C., Roy, J. M., and Bensafi, M. (2019). Individual differences as a key factor to uncover the nerual underpinnings of hedonic and social funtions of human olfaction: current findings from PET and FMRI studies and future considerations. Brain Topogr. 32, 977-986. doi: 10.1007/s10548-01900733-9

Martins, Y., Preti, G., Crabtree, C. R., Runyan, T., Vainius, A. A., and Wysocki, C. J. (2005). Preference for human body odors is influenced by gender and sexual orientation. Psychol. Sci. 16, 694-701. doi: 10.1111/j.1467-9280.2005.01598.x

Melis, M., Sollai, G., Masala, C., Pisanu, C., Cossu, G., Melis, M., et al. (2019). Odor identification performance in idiopathic Parkinson's disease is associated with gender and the genetic variability of the olfactory binding protein. Chem. Senses. 44, 311-318. doi: 10.1093/chemse/bjz020

Moberg, P. J., Arnold, S. E., Doty, R. L., Kohler, C., Kanes, S., and Seigel, S. (2003). Impairment of odor hedoncis in men with schizophrenia. Am. J. Psychiatry. 160, 1784-1789. doi: 10.1176/appi.ajp.160.10.1784

Moncrieff, R. W. (1966). Odour Preferences. London: Leonard Hill.

Mutic, S., Moellers, E. M., Wiesmann, M., and Freiherr, J. (2016). Chemosensory communication of gender information : masculanity bias in body odor perception and feminity bias introduced by chemosignals during social perception. Front. Psychol. 6:1980. doi: 10.3389/fpsyg.2015.01980

Natsch, A., and Emter, R. (2020). The specific biochemistry of human axilla odour formation viewed in an evolutionary context. Philosophical. Trans. R. Soc. B. 375:20190269. doi: 10.1098/rstb.2019.0269

Nordin, S., Bende, M., and Millqvist, F. (2004). Normative data for the chemical sensitivity scale. J. Environ. Psychol. 24, 399-403. doi: 10.1016/S0272-4944(03) 00074-4

Novembre, G., Andzi, R., and Morrison, I. (2021). Hedonic responses to touch are modulated by the perceived attractiveness of the caresser. Neuroscience 464, 79-89. doi: 10.1016/j.neuroscience.2020.10.007

Olatunji, B. O., Williams, N. I., Tolin, D. E., Abramowitz, J. S., Sawchuk, C. N., Lohr, J. M., et al. (2007). The disgust scale: items analysis, factor structure, and suggestions for refinement. Psychol. Assess. 19, 281-297. doi: 10.1037/10403590.19.3.281

Olofsson, J. K., and Nordin, S. (2004). Gender differences in chemosensory perception and event-related potentials. Chem. Senses. 29, 629-637. doi: 10. 1093/chemse/bjh066

Pichon, A. M., Coppin, G., Cayeux, I., Porcherot, C., Sander, D., and Delplanque, S. (2015). Sensitivity of physiological emotional measures to odors depends on the product and the pleasantness ranges used. Front. Psychol. 6:1821. doi: 10.3389/fpsyg.2015.01821

Platek, S. M., Burch, R. L., and Gallup, G. G. (2001). Sex differences in olfactory selfrecognition. Physiol. Behav. 73, 635-640. doi: 10.1016/S0031-9384(01)00539$\mathrm{X}$

Postolache, T. T., Wehr, T. A., Doty, R. L., Sher, L., Turner, E. H., and Barko, J. J. (2002). Patients with seasonal affective disorder have lower odor detection thresholds than control subjects. Arch. General Psychiaty 59, 1119-1122. doi: 10.1001/archpsyc.59.12.1119

Preti, G., Cutler, W. B., Garcia, C. R., Huggins, G. R., and Lawley, H. J. (1986). Human axillary secretions influence women's mentrual cycles : the role of donor extract of females. Hormones Behav. 20, 474-482. doi: 10.1016/0018-506X(86) 90009-7

Preti, G., Wysocki, C. J., Barhart, K. T., Sondheimer, S. J., and Leyden, J. J. (2003). Male axillary extracts contain pheromones that affect pulsatile secretion of luteinizing hormone and mood in women recipients. Biol. Reproduc. 68, 2107-2113. doi: 10.1095/biolreprod.102.008268

Rabin, M. D., and Cain, W. S. (1986). Determinants of measured olfactory sensitivity. Perception Pyschophysics 39, 281-286. doi: 10.3758/BF03204936

Robabeh, S., Mohammad, J. M., Reza, A., and Mahan, B. (2015). The evaluation of olfactroy function in patients with schizophrenia. Global J. Health Sci. 7, 319-330. doi: 10.5539/gjhs.v7n6p319

Rosa, A., Isola, R., Nieddu, M., and Masala, C. (2020). The role of lipid composition in the sensory attributes and acceptability of the salted and dried mullet roes (bottarga) : a study in human and animal models. Nutrients 12:3454. doi: 10.3390/nu12113454

Royet, J. P., Plailly, J., Delon-Martin, C., Kareken, D. A., and Segebarth, C. (2003). fMRI of emotional responses to odors: influence of hedonic valence and judment, handedness and gender. NeuroImage 20, 713-728. doi: 10.1016/ S1053-8119(03)00388-4

Ruser, P., Koeppel, C. J., Kitzler, H. H., Hummel, T., and Croy, I. (2021). Individual odor hedonic perception is coded in temporal joint network activity. NeuroImage 229:117782. doi: 10.1016/j.neuroimage.2021.117782

Schiffman, S. S. (1974). Physicochemical correlates of olfactory quality. Science 185, 112-117. doi: 10.1126/science.185.4146.112

Schirmer, A., Kotz, S. A., and Friederici, A. D. (2002). Sex differentiates the role of emotional prosody during word processing. Cogn. Brain Res. 14, 228-233. doi: 10.1016/S0926-6410(02)00108-8

Schirmer, A., Striano, T., and Friederici, A. D. (2005). Sex differences in the preattentive processing of vocal emotional expressions. Neuroreport 16, 635639. doi: 10.1097/00001756-200504250-00024

Seo, H. S., Buschhüter, D., and Hummel, T. (2008). Contextual influences on the relationship between familiarity and hedonicity of odors. J. Food Sci. 73, 273-278. doi: 10.1111/j.1750-3841.2008.00818.x

Seo, H. S., Lee, Y., Yoon, N. R., Song, J. M., Shin, J. M., and Lee, S. Y. (2009). Impacts of sensory attributes and emotional responses on the hedonic ratings of odors indairy products. Appetite 53, 50-55. doi: 10.1016/j.appet.2009.05.010

Seubert, J., Rea, A. F., Loughead, J., and Habel, U. (2009). Mood induction with olfactory stimuli reveals differential affective responses in males and females. Chem. Senses. 34, 77-84. doi: 10.1093/chemse/bjn054

Singh, D., and Bronstad, P. M. (2001). Female body odour is a potential cue to ovulation. Proc. R. Soc. B. 268, 797-801. doi: 10.1098/rspb.2001.1589

Sirota, P., Davidson, B., Mosheva, T., Benhatov, R., Zohar, J., and Gross-Isseroff, R. (1999). Increased olfactory sensitivity in first episode psychosis and the effect of neuroleptic treatment on olfactory snesitivity in schizophrenia. Psychiatric Res. 86, 143-153. doi: 10.1016/S0165-1781(99)00025-6

Solla, P., Masala, C., Liscia, A., Piras, R., Ercoli, T., Fadda, L., et al. (2020). Sexrelated differences in olfactory function and evaluation of possible confounding factors among patients with Parkinson's disease. Neurology 267, 57-63. doi: 10.1007/s00415-019-09551-2

Sorokowski, P., Harkowski, M., Misiak, M., Konstancja Marczak, M., Dziekan, M., Hummel, T., et al. (2019). Sex differences in human olfaction: a meta-analysis. Front. Psychol. 10:242. doi: 10.3389/fpsyg.2019.00242

Sorokowski, P., Sorokowska, A., and Witzel, C. (2014). Sex differences in color preferences transcend extreme differences in culture and ecology. Psychonomic Bull. Rev. 21, 1195-1201. doi: 10.3758/s13423-014-0591-8

Soudry, Y., Lemogne, C., Malinvaud, D., Consoli, S. M., and Bonfils, P. (2011). Olfactory system and emotion : common substrates. Eur. Ann. Otorhinolar. Head Neck Dis. 128, 18-23. doi: 10.1016/j.anorl.2010.09.007

Stevenson, R. J., and Repacholi, B. M. (2003). Age-related changes in children's hedonic response to male body odor. Dev. Psychol. 39, 670-679. doi: 10.1037/ 0012-1649.39.4.670

Swiecicki, L., Zatorski, P., Bzinkowska, D., Sienkiewicz-Jarosz, H., Szyndler, J., and Scinska, A. (2009). Gustatory and olfactory function in patients with unipolar and bipolar depression. Prog. Neuro Psychopharmacol. Biol. Psychiatry 33, 827-834. doi: 10.1016/j.pnpbp.2009.03.030

Thuerauf, N., Reulbach, U., Lunkenheimer, J., Spannenberger, R., and Gossler, A. (2009). Emotional reactivity to odors: olfactory sensitivity and the span of emotional evaluation separate the genders. Neurosci. Lett. 456, 74-79. doi: 10.1016/j.neulet.2009.03.096

Trellakis, S., Tagay, S., Fischer, C., Rydleuskaya, A., Scherag, A., Bruderek, K., et al. (2011). Ghrelin, leptin and adiponectin as possible predictors of the hedonic value of odors. Regulatory Peptides 167, 112-117. doi: 10.1016/j.regpep.2010. 12.005

Triscoli, C., Croy, I., Olausson, H., and Sailer, U. (2014). Liking and wanting pleasant odors: different effects of repetitive exposure in men and women. Front. Psychol. 5:526. doi: 10.3389/fpsyg.2014.00526

Tullio Luizza, M., Lindholm, T., Hawley, C., Gustafsson Senden, M., Ekström, I., Olsson, M. J., et al. (2017). The body odor disgust scale (BODS): Development and validation of a novel disgust assessment. Chem. Senses. 42, 499-508. doi: 10.1093/chemse/bjw107 
Turetsky, B. I., Hahn, C. G., Borgmann-Winter, K., and Moberg, P. J. (2009). Scents and nonsense: olfactory dysfunction in schizophrenia. Schizphrenia Bull. 35, 1117-1131. doi: 10.1093/schbul/sbp111

Wallrabenstein, I., Gerber, J., Rasche, S., Croy, I., Kurtenbach, S., Hummel, T., et al. (2015). The smelling of hedione results in sex-differentiated human brain activity. NeuroImage 113, 365-373. doi: 10.1016/j.neuroimage.2015.03.029

Walsh-Messinger, J., Wong, P. S., Antonius, D., McMahon, K., Opler, L. A., and Michael Ramirez, P. (2018). Sex differences in hedonic judgment of odors in schizophrenia cases and healthy controls HHS public assess. Psychiatry Res. 269, 345-353. doi: 10.1016/j.psychres.2018.08.058

Wester, S. R., Vogel, D. L., Pressly, P. K., and Heesacker, M. (2002). Sex differences in emotion: a critical review of the lierature and implications for counseling psychology. Counseling Pychol. 30, 630-652. doi: 10.1177/001000020300 04008

Williams, L. M., and Gordon, E. (2007). Dynamic organization of the emotional brain: responsivity,stability and instability. Neuroscientist 13, 349-370. doi: 10.1177/10738584070130040801

Woodward, M. R., Amrutkar, C. V., Shah, H. C., Benedict, R. H., Rajakrishnan, S., Doody, R. S., et al. (2017). Validation of olfactory deficit as a biomarker of Alzheimer disease. Neurol. Clin. Pract. 7, 5-14. doi: 10.1212/CPJ. 0000000000000293

Wysocki, C. J., and Beauchamp, G. K. (1984). Ability to smell androstenone is genetically determined. Proc. Natl. Acad. Sci. U.S.A. 81, 4899-4902. doi: 10. 1073/pnas.81.15.4899
Wysocki, C. J., and Gilbert, A. N. (1989). National geographic smell survey: effects of age are heterogeneous. Ann. N.Y. Acad. Sci. 561, 12-28. doi: 10.1111/j.17496632.1989.tb20966.x

Zou, L. Q., van Hartevelt, T. J., Kringelbach, M. L., Cheung, E. F. C., and Chan, R. C. K. (2016). The neural mechanism of hedonic processing and judgment of pleasant odors: an activationl likelihood estimation meta-analysis. Neuropsychology 30, 970-979. doi: 10.1037/neu0000292

Conflict of Interest: The authors declare that the research was conducted in the absence of any commercial or financial relationships that could be construed as a potential conflict of interest.

Publisher's Note: All claims expressed in this article are solely those of the authors and do not necessarily represent those of their affiliated organizations, or those of the publisher, the editors and the reviewers. Any product that may be evaluated in this article, or claim that may be made by its manufacturer, is not guaranteed or endorsed by the publisher.

Copyright (c) 2021 Bontempi, Jacquot and Brand. This is an open-access article distributed under the terms of the Creative Commons Attribution License (CC BY). The use, distribution or reproduction in other forums is permitted, provided the original author(s) and the copyright owner(s) are credited and that the original publication in this journal is cited, in accordance with accepted academic practice. No use, distribution or reproduction is permitted which does not comply with these terms. 